\title{
Maturity Model for Service Engineering
}

\author{
Clemens FISCHER, Magdalena BRUNNHOFER
}

\begin{abstract}
Nowadays, the mere sale of physical products is often no longer sufficient for the long-term success of companies. Actually, the combination of physical products with services as a product-service bundle should be offered. Based on this initial situation, this article provides an analysis model for the plant manufacturer industry with a special focus on the maturity level of services. The analysis model shows both, the existent level of service maturity in a company and the steps, which are required to the next higher level of maturity in this model. After the theoretical conception of the model, it is validated practically through a questionnaire and a service maturity portfolio. The outcome shows, on the one hand the content suitability of the maturity model and on the other, it provides initial conclusions concerning the present service degree of maturity in companies.
\end{abstract}

Keywords: management; maturity model; product-service bundle; service engineering; service innovation; strategy

\section{INTRODUCTION}

Due to the increasing global convergence of producers and consumers, companies have already recognized that the sale of their high-quality physical products is no longer sufficient to establish a long-term market presence. Especially plant manufacturers are characterized by homogeneity in terms of technology and quality. Therefore, products are more and more similar to the customer and, consequently, exchangeable. A form of market differentiation that counteracts this trend is to extend the classic product portfolio with product-related services. The resulting product-service bundle can generate additional revenues and thus lead to a sustainable competitive advantage. As a result, differentiation from competition can be achieved [1].

However, entering the service market requires innovative ideas that may ultimately lead to a modification of the existing business model of the company. In some companies such changes are already recognizable, in many others, especially SMEs, the service idea is not yet far advanced [2].

Although there are many approaches to the creation of innovative services in theory [3-7], decisions for new services are often merely based on instinct in practice. Although this procedure is likely to be successful in a few cases, many companies will potentially fail when applying this strategy. It can be argued that a systematic approach for the development of innovative services is necessary in order to increase the chance of success. In order to implement this development in a structured manner, it is necessary to determine which characteristics the future services should have. Basically, the expression "service" is a broad term, ranging from simple support activities (e.g. warranty services, training, commissioning) to production improvements at the customer site (e.g. process optimization, modernization). In its highest form of expression, services can even be understood as new business opportunities for the provider. In order to determine the service characteristics, maturity models, representing the different forms of services in companies, have been established in recent years.

In the course of this paper, an analysis approach for the plant manufacturer industry will be provided with special focus on the maturity level of services. The utilized maturity model (Fig. 3) indicates in which level of service maturity the company is currently located and which innovative service can be derived from it. It also clarifies which steps are required to reach the next higher level of the maturity model.

In order to achieve these objectives, a theoretical analysis of the topic service engineering is provided in the beginning of this paper. This literature review includes success factors, reasons for failed services as well as the description of a procedure plan for service development. Next, different maturity models, which describe an evolutionary path of services, are discussed and compared. This forms the basis for the development of a five-level maturity model for service engineering. Finally, the practical application of the maturity model is discussed in detail.

\section{SERVICE ENGINEERING}

Due to manifold reasons (e.g. increasing competitive intensity, shorter product life cycles, complex markets) plant manufacturers are currently facing challenges to remain successful in the long term [8]. To counteract this development new strategies are necessary. One possibility is the extension of the classic product portfolio with services and, thus, offering an individual product-service bundle [6-10]. Depending on the sector of a company, its customer structure and the offered products, different types of services can be distinguished for such bundle: [11-13]

- $\quad$ Service as a product support or sales support.

- Service to assist users and customers, providing knowledge about the machine and its processes.

- Service to support the customer's business, whereby even individual processes migrate away from the customer and implementation becomes the sole task of the provider (also called "extended workbench").

Service Engineering uses well-known and established methods of product development in the service area in order to support the identification of latent potentials in the service processes, to develop new industrial opportunities and to improve the quality of services [14]. The efficient and systematic use of service engineering methods aims at achieving various objectives: An important objective is the development of services of superior quality. On the one 
hand, this includes the quality of the final service in a short, medium and long-term range. On the other hand, quality means the reduction of undesirable developments, and the increase of successful service innovations. Based on this, lower development costs and reduced time-to-market can be achieved. The quality of services is also reflected in customer satisfaction. Active participation of the customer during the service development process can also have a positive impact on the satisfaction level in terms of the quality. Another objective is customer orientation, which is also related to the aforementioned points. It is important to adapt new services in order to fulfil the customers' needs and wishes and, to involve the customers in the development process. This will increase customer satisfaction and results in a long-term customer relationship $[15,16]$.

In order to introduce the product-service bundle successfully on the market, systematic service development is required. Otherwise, the service is doomed to fail with high probability. According to Spath et al. [17] about $45 \%$ of newly developed services fail within the first year of their launch. There are different reasons for failure: Firstly, the decision to develop new services is often made based on instinct alone and, therefore, not sufficiently thought through. This unsystematic approach can usually be explained by the fact that employees are not adequately aware of appropriate methods and tools for such service innovation. Secondly, customer needs are insufficiently taken into account. Thirdly, daily business has also negative impact on the development of new services. Due to the employees' high workload, innovation cannot be carried out adequately. As a consequence, possible weak points are not likely to be immediately recognized [18-20].

To reduce the likelihood of failure of a service innovation, a systematic service development approach is required. Service engineering provides a suitable framework to resolve this issue. The development of services should be systematized with clearly defined steps and corresponding activities. For this purpose, different process models are described in literature [17]. Prototyping mock-ups or iterative phase approaches are preferable for the development of complex services. For less extensive services, simple linear procedures are sufficient [15-16; 19]. In general, these process models are divided into separate phases, which run sequentially or iteratively, as seen in Fig. 1. At the beginning (phase 1) ideas for new services are generated both within the company (e.g. R\&D department) and/or with external support (e.g. customer survey). An initial rough estimation of whether the idea is marketable or not, is already conducted in this early stage. In a subsequent in-depth analysis (phase 2), the idea must be merged with the requirements of the customer and the company. In the design phase, the results of the previous analysis are merged into a service specification and considered a starting point for the creation of a service model and a marketing concept (phase 3). During the subsequent concept phase, a plan, which includes the necessary steps for the service implementation, is created (phase 4). If the new service is ready for usage, it will be finally checked and implemented in the market afterwards (phase 5-6) [15].

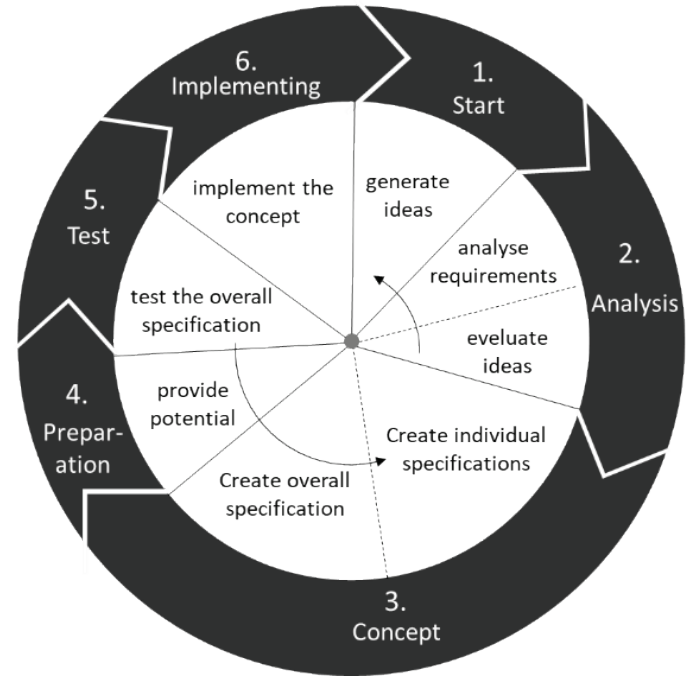

Figure 1 Iterative procedure model for service development [13, 16, 19]

Especially phases 1 to 4 are very complex and timeconsuming. At the same time, these early phases before and during the development of the service are of crucial importance for later success. Important, and above all, correct decisions must be made during these phases, although the level of information is usually low and often only assumptions can be made [21].

\section{MATURITY MODEL}

The development of a company from a purely plant manufacturer to a provider of product-service bundles requires a step by step approach as well as the acquisition of additional skills. Systematic maturity models make vital contributions in this change process [22].

\subsection{Maturity Models in Literature}

Maturity models are based on the assumption that there are predictable patterns in the development of organizations. These patterns can be described as evolutionary stages or maturity levels and represent a logical or desired evolutionary path to the highest maturity [23-24]. Maturity models have been developed in the field of software design in recent decades and have mostly been used in large companies (e.g. for risk minimization during IT implementations) [25]. Nowadays the application of maturity models is no longer limited to the IT sector and large companies. Rather, diverse application scenarios are known (e.g. purchasing [26]; automotive industry [27]; quality management [28]). As visualized in the following Fig. 2, maturity models for the service area are discussed by different authors [23, 29-34].

As seen in Fig. 2, earlier procedures just make a rough division of the maturity stages. For example, in the approach of Beyer [29] (2007) three levels of maturity of service developments within companies are identified. Beyer postulated that a pure manufacturer does not have strong ambitions to offer services as part of his portfolio. The subsequent service providing manufacturer perceives services as an opportunity to increase the profit margin and to use the direct customer feedback to produce closer to the market. In the third stage of the Maturity Model according to Beyer a manufacturing company has become a 
producing service provider, offering the customer a holistic solution [31]. By contrast, in later models (e.g. [2]) a finer breakdown of maturity stages is made. Yet, the rough division of maturity stages may provide a first guideline. In practice, however, a more detailed breakdown seems more appropriate for the derivation of tangible measures for the service development

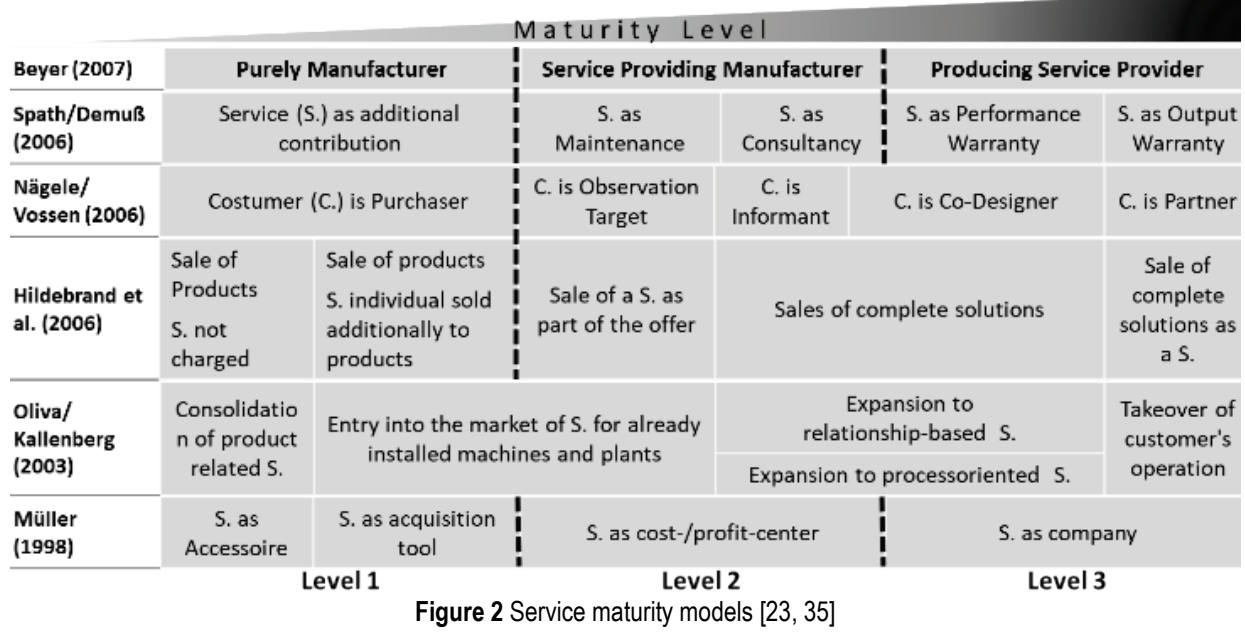

\subsection{Five-Level Maturity Model for Service Engineering}

The models previously discussed, represent the basis for the derivation of the maturity model of service engineering. Based on these well-known approaches the development phases of services are also subdivided into five different maturity levels (Fig. 3). The maturity model of service engineering contains a range of services within each level. Depending on complexity and extent of the respective services, certain skills are necessary in order to implement the service successfully within the company. Through the utilization of the model, companies are able to classify their current range of services and either fully exploit the potential of each stage or evolve in such manner to reach the next higher level.

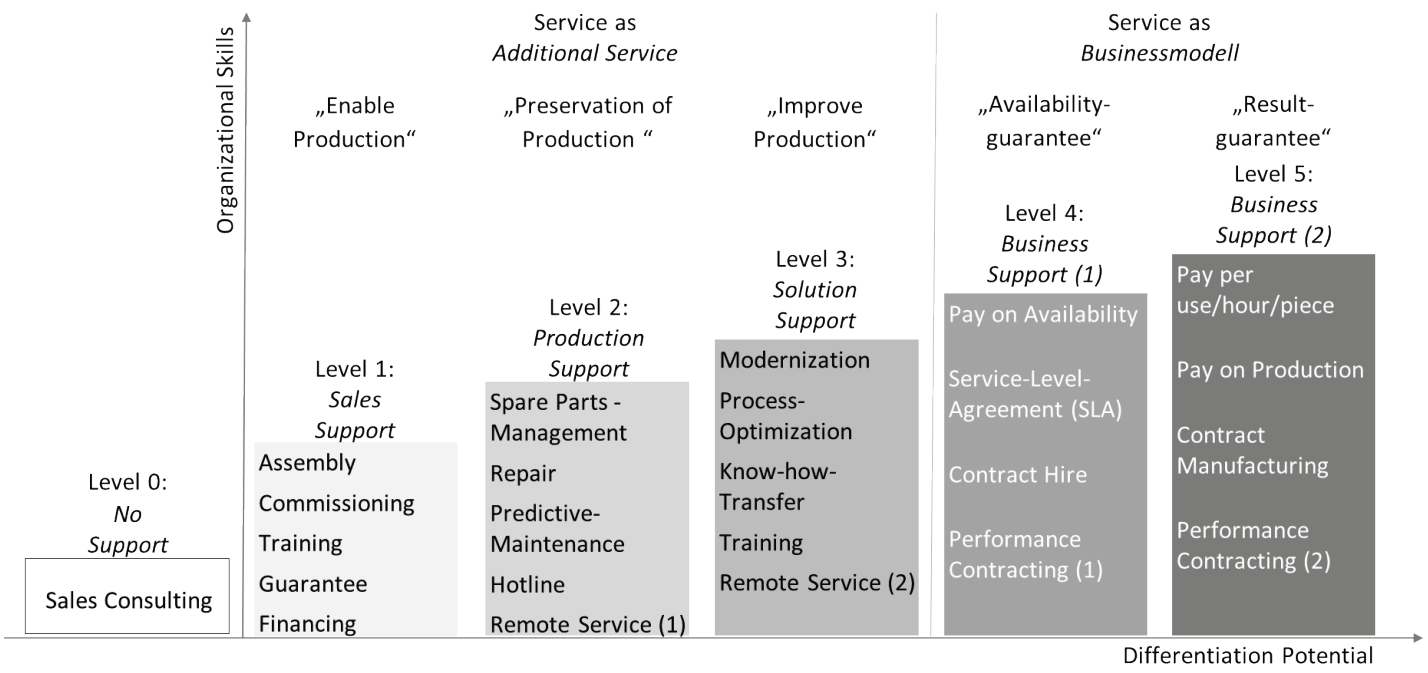

Figure 3 Maturity model for service engineering (own illustration based on [2, 30,36])

Companies that are in level 0 offer no significant services except consulting services to support the customer with the purchasing decision. Services that operate in the maturity levels 1 to 3 are offered in addition to the classic product. Therefore, companies focus on the sale of the physical product, while the offered services just serve to support and improve the product. Within levels 4 and 5 the service is offered as an independent and new business model. Therefore, the focus is no longer on the sale of the product, but on the availability of the equipment to the customer. Overall, services from level 1 to 3 promote the sale of the product, while in level 4 and 5 the sale of the service is focal and facilitates the sale of the product. The levels within the model build on each other. This means that, for example, level 3 can only be achieved if the services in the lower levels are adequately mastered [2]. An in-depth description of the levels can be found in the following chapter 3.4 .

The selection of services as well as their respective level was made with focus on plant manufacturers. If the maturity model is being applied to other industries, the services have to be adjusted. Objective and valid results can only be achieved through industry-specific adaptation of the model, which are also suitable for benchmark comparisons. 


\subsection{Maturity-Levels in Detail}

Companies that are in the first level of the maturity model for service engineering offer services to their customer in order to help to manufacture their products. This includes the installation and commissioning of plants, but also financing options or guarantees as sale support. In the second level, the production-performance of the customer is supported directly at the customer site. At this level you can find conventional services, such as after-sales and spare parts management, preventive maintenance, inspections or repair services. In the third level an optimized use of goods is ensured by the support of services in order to reduce costs on the customer side through optimized processes [40]. Such services can include e.g. the modernization of facilities through new components as well as process optimization based on know-how transfer, and trainings or the application of lean production methods.

Furthermore, the availability of the machines and their utilization can be increased by means of further remote service. By the use of remote diagnostics, defective parts can be detected early. Thus, preventive maintenance and repair measures can alleviate problems before costly equipment failure [36]. At an advanced stage of remote service, customer operating data and parameters are remotely analyzed and adapted. As a result, for example, the output is increased or the energy / material consumption is reduced. With this application, the company is relatively deeply involved in data analytics [37-39]. From the fourth level onwards, the focus of the company is no longer the sale of the physical product, but the availability of the equipment at the customer for which user fees may be charged on pay-one-availability models. The main interest of the manufacturer is the permanent operational readiness of the plant, as the customer pays depending on the technical availability. The advantage of such a model is that the customer does not have to make large investments. This is an advantage which can be considered particularly important in the SME sector [36]. In performance contracting, the company provides a service-bundle at a fixed price to the customer. This bundle includes a physical product (e.g. plant, machine) in combination with a specific performance target (e.g. a certain plant availability of $95 \%$ ) and a full service over a certain period. Although the product is used by the customer, it remains the legal property of the manufacturer. Thus, the manufacturer bears the risk of default, but not the responsibility for the employees or the management [30, $36,38]$. In the final fifth level of the model, in addition to the plant or machine, the manufacturer also provides the operating personell and handles the full amount of in-kind contribution. This represents an extension of performance contracting from the fourth stage. In this case, the serviceproviding company also assumes the risks relating to the operation management, as well as operating errors and misuse [30].

\section{METHODOLOGY}

The introduced maturity model for service engineering should now be validated concerning its practical applicability. For this, a simple validation method is designed on the basis of theoretical knowledge and tested by industry experts afterwards. The results of this method are intended to verify, on the one hand, the content suitability of the maturity model. On the other hand, the results aim at providing initial conclusions regarding the present service level maturity in companies. The validation method consists of a questionnaire, by means of which companies assess their serviceability. The development of the questionnaire showed that a simple classification into only one of the described maturity levels does not make sense in practice. This can be explained by the fact that hardly any company actually performs services only on one level. Rather, it is a combination of different services, which in turn are assigned to separate maturity levels. For this reason, all services that are included within maturity model are thematically clustered. The clustering results in five different service areas (pre-sales consulting, support, expertise, production and plant availability), represent the essential services offered by industrial plant manufacturers.

These areas are subsequently assigned different services, which simultaneously represent the various forms of maturity (see Fig. 4). In addition, the services are described with an easily understandable sentence in order to facilitate the response process in the questionnaire. The basis for the preparation of the questionnaire, in particular the associated services, was upstream literature analysis.

\begin{tabular}{|c|c|c|c|c|c|}
\hline Level & $\begin{array}{c}\text { Pre- } \\
\text { Sales Consulting }\end{array}$ & Support & Expertise & Production & Plant Availability \\
\hline 1 & Quoting & Mounting & Documentation & Guarantee & Commissioning \\
\hline 2 & $\begin{array}{c}\text { Maintenance } \\
\text { (foreign } \\
\text { products) }\end{array}$ & Financing & Training & $\begin{array}{c}\text { Spare Part } \\
\text { Management }\end{array}$ & Maintenacne \\
\hline 3 & $\begin{array}{c}\text { Process } \\
\text { Development }\end{array}$ & $\begin{array}{c}\text { Remote Service } \\
1\end{array}$ & Hotline & $\begin{array}{c}\text { Vendor } \\
\text { Management } \\
\text { Inventory (VMI) }\end{array}$ & Modernization \\
\hline 4 & Simulation & $\begin{array}{c}\text { Remote Service } \\
2\end{array}$ & $\begin{array}{l}\text { Knowhow- } \\
\text { Transfer }\end{array}$ & $\begin{array}{c}\text { Performance } \\
\text { Contracting }\end{array}$ & $\begin{array}{c}\text { Pay on } \\
\text { Availability }\end{array}$ \\
\hline 5 & $\begin{array}{l}\text { Experimente } \\
\text { / Tests }\end{array}$ & $\begin{array}{l}\text { Service Level } \\
\text { Agreement }\end{array}$ & $\begin{array}{c}\text { Process- } \\
\text { optimization }\end{array}$ & $\begin{array}{c}\text { Contract } \\
\text { Manufacturing }\end{array}$ & Pay per Unit \\
\hline
\end{tabular}

Figure 4 Services in separate levels

In the next step, the experts for the survey were selected. In order to obtain a qualified statement about the practical applicability of the maturity model, the experts must already have both, experience in manufacturing and initial experience in the service area. Both criteria apply to the participants of the working group "Service Design \& Engineering". The group consists of representatives from different Austrian manufacturing companies and aims to 
further develop the range of services by working together and learning from best practices. In total, 20 companies of the working group were invited to participate in the survey, whereby finally, nine experts from different companies completed the questionnaire. Afterwards, the results were evaluated, visualized and discussed with the company representatives. In the course of the discussion, not only the results, but also the contents of the questionnaire were critically reflected.

Generally, the validation method allows companies to classify their maturity level supported by the questionnaire. This enables companies to independently identify which services they already offer at the respective level and what kind of services are needed to reach a higher level.

\section{RESULTS AND PRACTICAL APPLICATION}

In Fig. 5 an exemplary result of the maturity questionnaire completed by a plant manufacturer is shown. The range of services of this plant manufacturer is illustrated and shows that he offers specific services in the pre-sales phase. As part of the company's support services to the customer, standard services such as assembly are offered. In addition, the customer is provided with a financing possibility by a business partner of the provider. Furthermore, the customer can use the remote maintenance service in order to receive regular software updates. With the sale of the plant to the customer also expertise is handed over. Besides a detailed system documentation, the manufacturer also offers trainings for employees. For short-term information, a service hotline is implemented by the plant manufacturer. On the production side, the manufacturer guarantees perfect technical operation of the system. In addition, the customer has the option to order spare parts from the manufacturer. Next to this, the manufacturer offers a certain level of performance to ensure plant availability. This includes the preparation for use and the commissioning in the course of a trial operation. Furthermore, the manufacturer carries out standardized maintenance and servicing in a contractually regulated period.

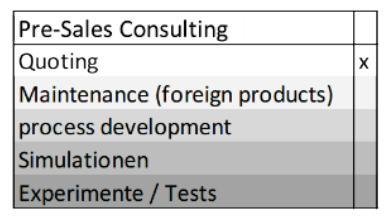

\begin{tabular}{|l|l|}
\hline Expertise & \\
\hline Documentation & $\mathrm{x}$ \\
Training & $\mathrm{x}$ \\
Hotline & $\mathrm{x}$ \\
Know-how transfer & \\
Process Optimization & \\
\hline
\end{tabular}

\begin{tabular}{|l|c|}
\hline Plant Availability & \\
\hline Commissioning & $\mathrm{x}$ \\
Maintenance & $\mathrm{x}$ \\
Modernization & \\
Pay on Availability & \\
Pay per Unit & \\
\hline
\end{tabular}
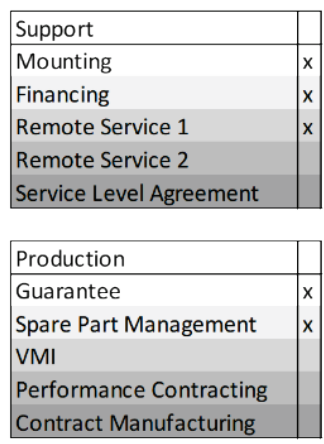

$x=$ Service is offered

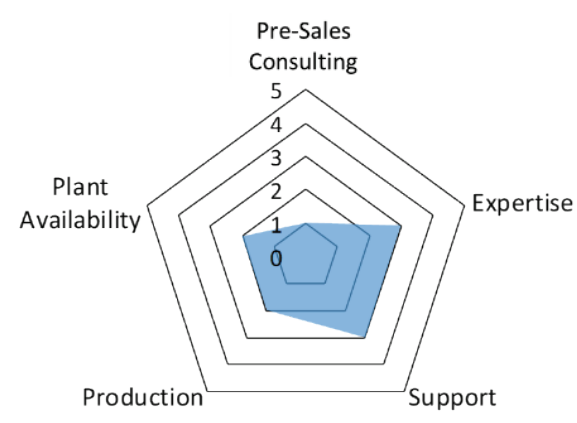

\begin{tabular}{|l|c|}
\hline \multicolumn{1}{|c|}{ Servicecategory } & Degree of Maturity \\
\hline Before Purchase & 1 \\
Expertise & 3 \\
Support & 3 \\
Production & 2 \\
Plant Availability & 2 \\
\hline
\end{tabular}

Figure 5 Overview service maturity portfolio

The innovation in service engineering described in this article relates to the result of the questionnaire and the resulting spider web diagram. By using this method, companies in this industry can compare and see at a glance where there is room for improvement once this method has become established.

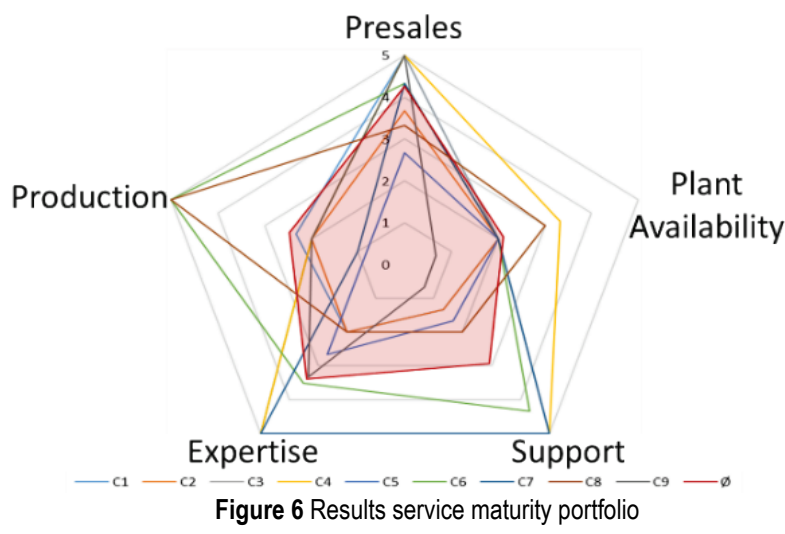

The result of the service portfolio shows that the manufacturer already offers some services that indicate the first maturity level. Next to this, the company offers also second-stage services in four levels and third-party services in two levels. The example company has the possibility to reach at least the second stage in which the servicing of third-party products is also offered. This, in turn, would increase the company's profile and knowledge of third-party products. An expansion of the service offering to level three should be strategically discussed within the company.

The designed questionnaire to assess the current degree of maturity per service area was subsequently completed by the selected companies, evaluated and visualized. The summarized results of all nine companies are shown in Fig. 6. The figure shows the degree of maturity per service area for each of the nine companies (C1-C9) as well as an average value across all companies (Ø). It can be seen that five of the companies have already reached the highest service level in one or more areas. In contrast, in some areas there have been no services so far. 
This is due to the fact that these services are not common or lucrative for the participating companies.

In detail, the results of the service portfolio show that in most cases (especially in the pre-sales phase), companies strive to provide the customer with a high quality and advanced service. As is in most high-wage countries like Austria, companies primarily rely on the knowledge of the employees, which is usually available to a high degree. These services in this early phase of the customer lifecycle are not only beneficial to the customer, but also have positive effects for the company itself. Thus, a company that exudes high know-how competencies will also be perceived as an innovator on the labour market. The results of the survey also reveal a clear trend. Concepts such as "pay on availability" have already been considered and preparatory measures for offering this comprehensive service have already been carried out. Services such as commissioning, maintenance and servicing have long been a long-term component of the companies' service portfolios. Due to the steadily increasing digitization of production, modernization in the sense of retrofitting is already being offered. Thus, the life of a capital asset of customers can be significantly extended. In order to keep the contact with the customer, some companies support the customer in the use of the equipment for years. This support starts with the purchase with financing offers, the assembly of the equipment and then swing into long-term remote services packages and in some cases up to service level agreements. This connection to the customer is often also found in production, when some companies additionally carry out a "Vendor Management Inventory" or even "Contract Manufacturing" for the customer in addition to the usual offers like warranties and spare part management. However, the frequency of these services offered is limited.

\section{CONCLUSION AND LIMITATIONS}

Through the application of maturity models, companies can obtain an overview of the market and determine the status quo of the current service offerings. They also show which services are currently provided in various industries. The literature offers companies several types of approaches that describe the various types of possibilities to add value for the customer. The maturity model of service engineering is based on the comparison of different methods, providing a specific classification of differential services in divergent levels.

A basic idea of the maturity model is the usage as a process for the systematic change of business plans of a company. For one thing, the separate levels or the individual services in these levels can also be offered separately. Then again, however, each properly thought through offer of a service builds on specific prior knowledge. Plant manufacturers, who have already converted their business plan to services, usually have this prior knowledge of the upstream services. If a company wants to offer a special service, this service can also be classified visually using the maturity model. This classification into this approach enables the company to gain insight into the necessary skills and knowledge needed to deliver this service. Furthermore, it can be understood whether in the previous planning certain aspects were left out of consideration. With these findings, a company is able to plan the future strategy and milestones to achieve the particular service, include it in the budgeting process and promote the corresponding organizational changes.

The validation of the maturity model of service engineering showed that the model in its present form is difficult to use in practice. This can be explained by the fact that companies are classified at a low level of maturity with certain services and at a higher level of maturity with others. Therefore, no blanket classification into just one maturity level per company is possible. The questionnaire, which was specifically designed, enables a more complex consideration of the service level in each area of the company. However, the presented maturity model of service engineering does not reflect this yet, so a corresponding extension or detailing of this strategy would be necessary. In addition, further development of the questionnaire would be necessary so that the intensities and the depth of the services offered can also be included in the status elicitation. This would be possible by extending and supplementing the current phrasing of the questions.

Another limiting factor is that the presented maturity model is linked to the special conditions of plant manufacturers. Therefore, it has no general validity and cannot be applied to other industries in the current form. Consequently, it is necessary to re-sharpen the maturity model to the effect that it can be used in various industries. Customers in these different industries have divergent needs, and technological solutions and services offer a variety of hybrid service bundles. A unified questionnaire for different industries would allow cross-industry benchmarking and benefit from the disparate experiences.

\section{REFERENCES}

[1] Richter, H. M., Brunnhofer, M., Fischer, C., \& Tschandl, M. (2018). Management Roadmap zur Strategiefindung von neuen Services. In: Bruhn, M. \& Hadwich, K. Service Business Development, 141-165, Wiesbaden, Germany: Springer. https://doi.org/10.1007/978-3-658-22426-4_7

[2] Richter, H. M. \& Tschandl, M. (2017). Service Engineering - Neue Services erfolgreich gestalten und umsetzen. In: Bruhn, M. \& Hadwich, K. Dienstleistungen 4.0, 157-184, Wiesbaden, Germany: Springer. https://doi.org/10.1007/978-3-658-17550-4_7

[3] Davies, R. \& Sigthorsson, G. (2013). Introducing the Creative Industries: From Theory to Practice, United Kingdom: SAGE.

[4] Haller, S. (2012). Dienstleistungsmanagement, Germany: Springer Gabler. https://doi.org/10.1007/978-3-8349-3548-9

[5] Kaplan, R. S. \& Norton, D. P. (2011). Using the Balanced Scorecard as a Strategic Management System. In Harvard Business Review Press: HBR's ten must read on strategy. Boston, MA: Harvard Business School Publishing.

[6] Edvardsson, B., Gustafsson, A., Kristensson, P., Magnusson, P., \& Matthing, J. (2006) Involving Costumers in new Service Development, London, UK: Imperial College Press. https://doi.org/10.1142/9781860948893

[7] Leimeister, J. M. (2012). Dienstleistungsengineering undManagement, Heidelberg, Germany: Springer Gabler. https://doi.org/10.1007/978-3-642-27983-6

[8] Scheidegger, L. D. \& Weiss, E. (2016). Kundenintegration als Methode der marktorientierten Leistungserstellung in der Sport- und Lifestylebranche. In Tokarski, K. O., Schellinger, J., \& Berchtold, P. Unternehmensentwicklung - Strategien 
und Instrumente aus Forschung und Praxis, 213-233. Wiesbaden, Germany: Gabler. https://doi.org/10.1007/978-3-658-00283-1_12

[9] Velamuri, V. K., Neyer, A.-K., \& Möslein, K.-M. (2010). Hybrid Value Creation: Understanding the Value Creating Attributes. In Böhman, T. \& Leimeister, J. M. Integration von Produkt \& Dienstleistungen - Hybride Wertschöpfung, 3-16, Norderstedt, Germany: Books on Demand.

[10] Sturm, F., Bading, A., \& Schubert, M. (2007). Investitionsgüterhersteller auf dem Weg zum Lösungsanbietet, Stuttgart, Germany: Fraunhofer IRB Verlag.

[11] Seegy, U. (2009). Dienstleistungskompetenz im Maschinenund Anlagenbau - Eine Untersuchung wesentlicher Handlungspotenziale und ihrer Auswirkungen, Wiesbaden, Germany: Springer. https://doi.org/10.1007/978-3-8349-9492-9

[12] Homburg, C., Faßnacht, M., \& Günther, C. (2002). Erfolgreiche Umsetzung dienstleistungsorientierter Strategien in Industrieunternehmen. Schmalenbachs Zeitschrift für betriebswirtschaftliche Forschung ( $\mathrm{ffbF}$ ), 54(6), 487-508. https://doi.org/10.1007/BF03372684

[13] Backhaus, K. \& Hahn, C. (2001). Marketing von investiven Dienstleistungen. In Bruhn, M. \& Meffert, H. Handbuch Dienstleistungsmanagement: Von der strategischen Konzeption zur praktischen Umsetzung, 75-101, Wiesbaden, Germany: Springer.

[14] Albrecht, K. \& Zamke, R. (2002). Service America! - Doing Business in the new Economy, Homewood, IL: Richard D Irwin Inc.

[15] Bullinger, H.-J. \& Schreiner, P. (2006). Service Engineering: Ein Rahmenkonzept für die systematische Entwicklung von Dienstleistungen. In Bullinger, H.-J. \& Scheer, A.-W. Service Engineering - Entwicklung und Gestaltung innovativer Dienstleistungen, 53-84, Berlin, Germany: Springer. https://doi.org/10.1007/3-540-29473-2_3

[16] Schuh, G., Gudergan, G., Senderek, R., \& Frombach, R. (2016). Service Engineering. In Schuh, G., Gudergan, G., \& Kampker A. Management industrieller Dienstleistungen, 169-199, Berlin, Germany: Springer Vieweg. https://doi.org/10.1007/978-3-662-47256-9_7

[17] Spath, D., Meiren, T., \& Lamberth, S. (2013).Trends und Perspektiven des Service Engineering. ZWF-Zeitschrift für wirtschaftlichen Fabrikbetrieb, 108(4), 193-194. https://doi.org/10.3139/104.013040

[18] Haller, S. (2015). Dienstleistungsmanagement - Grundlagen - Konzepte - Instrumente, Wiesbaden, Germany: Springer. https://doi.org/10.1007/978-3-658-05205-8

[19] Leimeister, J. M. (2012). Dienstleistungsengineering undManagement, Heidelberg, Germany: Springer Gabler. https://doi.org/10.1007/978-3-642-27983-6

[20] Eversheim, W., Liestmann, V., \& Winkelmann, K. (2006). Anwendungspotenziale ingenieur-wissenschaftlicher Methoden für das Service Engineering. In Bullinger, H.-J. \& Scheer, A.-W. Service Engineering - Entwicklung und Gestaltung innovativer Dienstleistungen, 423-442, Berlin, Germany: Springer https://doi.org/10.1007/3-540-29473-2_18

[21] Alam, I. (2006). Service innovation strategy and process: a cross-national comparative analysis. International Marketing Review, 23(3), 234-254. https://doi.org/10.1108/02651330610670433

[22] Böhmann, T. \& Leimeister, J. M. (2010). Integration von Produkt \& Dienstleistung: Hybride Wertschöpfung, Hamburg, Germany: Books on Demand.

[23] Becker, J., Knackstedt, R., \& Pöppelbuß, J. (2009). Entwicklung von Reifegradmodellen für das ITManagement - Vorgehensmodell und praktische Anwendung. WI-Wirtschaftsinformatik, Vol. 51, 249-260. https://doi.org/10.1007/s11576-009-0167-9
[24] Becker， J., Knackstedt， R., \& Pöppelbuß，J. (2010). Vergleich von Reifegradmodellen für die hybride Wertschöpfung und Entwicklungsperspektiven. In Proceedings of the sub-conference Integration of Product and Service - Hybrid Value Added: within the framework of the multi-conference Business Informatics (MKWI 2010), 109-121, Göttingen, Germany: Books on Demand.

[25] Anderegg, B. (2000). IT-Prozessmanagement effizient und verständlich, Wiesbaden, Germany: Springer Vieweg. https://doi.org/10.1007/978-3-322-84955-7

[26] Heß, G. (2015). Reifegradmanagement im Einkauf: Mit dem 15M-Reifegradmodell zur Exzellenz im Supply Management, Wiesbaden, Germany: Springer. https://doi.org/10.1007/978-3-658-09649-6

[27] Huber, W. (2016). Industrie 4.0 in der Automobilproduktion, Wiesbaden, Germany: Springer. https://doi.org/10.1007/978-3-658-12732-9

[28] Bender, K. (2005). Embedded Systems - qualitätsorientierte Entwicklung, Heidelberg, Germany: Springer. https://doi.org/10.1007/b138984

[29] Beyer, M. (2007). Servicediversifikation in Industrieunternehmen - Kompetenztheoretische Untersuchung der Determinanten nachhaltiger Wettbewerbsvorteile, Wiesbaden, Germany: Springer.

[30] Spath，D. \& Demuß，L. (2006): Entwicklung hybrider Produkte- Gestaltung materieller und immaterieller Leistungsbündel. In Bullinger, H.-J. \& Scheer, A.-W. Service Engineering - Entwicklung und Gestaltung innovativer Dienstleistungen, 463-502, Berlin, Germany: Springer. https://doi.org/10.1007/3-540-29473-2_20

[31] Nägele, R. \& Vossen, I. (2006). Erfolgsfaktor kundenorientiertes Service Engineering Fallstudienergebnisse zum Tertiarisierungsprozess und zur Integration des Kunden in die Dienstleistungsentwicklung. In Schneider, K., Bullinger H.-J., \& Scheer A.-W. Service Engineering - Entwicklung und Gestaltung innovativer Dienstleistungen, 521-543, Heidelberg, Germany: Springer. https://doi.org/10.1007/3-540-29473-2_22

[32] Hildebrand, K., Gebauer, H., \& Fleisch, E. (2006). Strategische Ausrichtung des Servicegeschäfts in produzierenden Unternehmen. In Barkawi, K., Baader, A., \& Montanus, S. (Edt.): Erfolgreich mit After Sales Services Geschäftsstrategien für Servicemanagement und Ersatzteillogistik, 73-94, Heidelberg, Germany: Springer. https://doi.org/10.1007/3-540-34548-5 5

[33] Oliva, R. \& Kallenberg, R. (2003). Managing the transition from products to services, International Journal of Service Industry Management, 14 (2), 160-172. https://doi.org/10.1108/09564230310474138

[34] Müller, R. (1998). Kommerzialisierung industrieller Dienstleistungen, Schesslitz, Germany: Rosch-Buch.

[35] Thieme, M. \& Meyer, K. (2014). Das Konzept eines ServiceLifecycle-Managements: Vom Produzenten zum Dienstleister. In Zinke, C. \& Meyer, K. Produkt- und Dienstleistungslebenszyklus-Management, Leipziger Beiträge zur Informatik, Vol. XLVI, 10-20, Germany: Leipzig.

[36] Schuh, G., Gudergan, G., \& Grefrath, C. (2016). Geschäftsmodelle für industrielle Dienstleistungen. In Schuh, G., Gudergan, G., \& Kampker A. Management industrieller Dienstleistungen, 65-104, Berlin Heidelberg, Germany Springer. https://doi.org/10.1007/978-3-662-47256-9_4

[37] Emmerich, V., Döbele, M., Bauernhansl, T., PaulusRohmer, D., Schatz, A., \& Weskamp, M. (2015). Geschäftsmodell-Innovation durch Industrie 4.0 - Chancen und Risiken für den Maschinen- und Anlagenbau, München, Germany: Fraunhofer IPA. 
[38] Porter, M. E. \& Heppelmann J. E. (2014). Wie Smarte Produkte den Wettbewerb verändern. Harvard Business Manager, 12/2014, 35-60.

[39] Iansiti, M. \& Lakhani, K. R. (2014). Digitale Erneuerung, Harvard Business Manager, 12/2014, 63-74.

[40] Osterwalder, A. \& Pigneur, Y. (2010). Business Model Generation, A handbook for visionaries, game changers, and challengers, Hoboken, New Jersey: John Wiley \& Sons

\section{Contact information:}

Clemens FISCHER, MSc in Eng.

(Corresponding author)

FH JOANNEUM University of Applied Science

Werk-VI-Straße 46, 8605 Kapfenberg, AUSTRIA

Clemens.Fischer@fh-joanneum.at

Magdalena BRUNNHOFER, PhD, MSc in Eng

FH JOANNEUM University of Applied Science

Werk-VI-Straße 46, 8605 Kapfenberg, AUSTRIA

Magdalena.Brunnhofer@fh-joanneum.at 